\title{
Butyrate induces apoptosis in murine macrophages via caspase-3, but independent of autocrine synthesis of tumor necrosis factor and nitric oxide
}

M.G. Ramos ${ }^{1}$, F.L.A. Rabelo ${ }^{1}$,

T. Duarte', R.T. Gazzinelli ${ }^{1,2}$ and J.I. Alvarez-Leite ${ }^{1}$
${ }^{1}$ Departamento de Bioquímica e Imunologia, Instituto de Ciências Biológicas, Universidade Federal de Minas Gerais, Belo Horizonte, MG, Brasil

${ }^{2}$ Centro de Pesquisas René Rachou, FIO CRUZ, Belo Horizonte, MG, Brasil

\author{
Correspondence \\ J.I. Alvarez-Leite \\ Departamento de Bioquímica e \\ Imunologia, ICB, UFM G \\ Caixa Postal 486 \\ 30161-970 Belo Horizonte, M G \\ Brasil \\ Fax: + 55-31-441-5963 \\ E-mail: alvarez@mono.icb.ufmg.br \\ Research supported by CNPq. \\ R.T. Gazzinelli and \\ J.I. Alvarez-Leite were the \\ recipients of research fellowships \\ from CNPq. M.G. Ramos and \\ F.L.A. Rabelo were the recipients \\ of graduate fellowships from $\mathrm{CNPq}$ \\ and CAPES, respectively.
}

Received August 13, 2001

Accepted November 28, 2001

\section{Abstract}

We demonstrated that $4 \mathrm{mM}$ butyrate induces apoptosis in murine peritoneal macrophages in a dose- and time-dependent manner as indicated by studies of cell viability, flow cytometric analysis of annexin- $\mathrm{V}$ binding, DNA ladder pattern and the determination of hypodiploid DNA content. The activity of caspase-3 was enhanced during macrophage apoptosis induced by butyrate and the caspase inhibitor z-VAD-FMK $(100 \mu \mathrm{M})$ inhibited the butyrate effect, indicating the major role of the caspase cascade in the process. The levels of butyrate-induced apoptosis in macrophages were enhanced by cotreatment with $1 \mu \mathrm{g} / \mathrm{ml}$ bacterial lipopolysaccharide (LPS). However, our data indicate that apoptosis induced by butyrate and LPS involves different mechanisms. Thus, LPS-induced apoptosis was only observed when macrophages were primed with IFN- $\gamma$ and was partially dependent on iNOS, TNFR1 and IRF-1 functions as determined in experiments employing macrophages from various knockout mice. In contrast, butyrate-induced macrophage apoptosis was highly independent of IFN- $\gamma$ priming and of iNOS, TNFR1 and IRF- 1 functions.
Key words

- Butyrate

- Apoptosis

- Caspase

- Nitric oxide

- Cytokine

- Macrophage

\section{Introduction}

Apoptosis is a process of programmed cell death which is essential in maintaining homeostasis of mammalian tissues. Apoptotic cell death usually occurs in a tightly regulated manner and uses well-conserved genetic mechanisms (1). The cellular processes leading to apoptosis induction are not completely understood, but an important event is the activation of a cascade of cysteine pro- teases named caspases (2), leading to cleavage of specific substrates involved in cell death. The activation of apoptotic genes will culminate in morphological and biochemical changes leading to chromatin condensation followed by nuclear condensation, DNA fragmentation and packing of nuclear fragments into multiple membrane-enclosed apoptotic bodies.

Macrophages play an important role in initiating, maintaining and resolving host in- 
flammatory responses. They are able to directly kill viruses, bacteria and parasites, to secrete several immune regulators, to process and present antigens, and to act as scavenger cells. However, macrophages do not always play a positive role in the homeostasis of the immune system. Under some circumstances, macrophages have deleterious effects on the host. They can be dangerous in situations of excessive production of free radicals, lytic enzymes and inflammatory cytokines (3), which cause extensive local damage and are responsible for many of the systemic symptoms associated with acute and chronic inflammation. If uncontrolled, macrophage activation can lead to the clinical syndrome of septic shock and to the death of the host $(4,5)$. Macrophages can also be deleterious to the organism when they become foam cells and contribute to the formation of atherosclerotic lesions. These dangers suggest that macrophages must be subjected to strict regulatory control. Apoptosis would seem a logical candidate to participate in macrophage regulation, as it is known to regulate other cells in the immune system such as activated T cells (6,7), B cells $(8,9)$ and granulocytes $(10)$.

Butyrate is a four-carbon fatty acid normally produced by bacterial fermentation of fiber in the intestine of mammals. This small fatty acid is also well known to have multiple effects on different malignant or normal cells. These effects include cell differentiation, modulation of different gene expression and inhibition of cell proliferation (11). Butyrate has been shown to induce apoptosis in many different cells of the immune system, including murine thymocytes, splenic T cells, human Jurkat $T$ cells (12) and lymphocytic leukemia cells (13). The mechanisms by which butyrate induces apoptosis in different cell types are not known, but there is evidence that butyrate cell death induced in some cancer cells is triggered via activation of the caspase cascade (14). Butyrate could be important in the regulation of macro- phage apoptosis in situations where these cells are uncontrolled such as in atherosclerotic lesions and in the treatment of some types of leukemia with chemotherapeutic drugs. Butyrate control of macrophage apoptosis can also be important in bacterial infections induced by Shigella and Salmonella (15) and in periodontitis (16) since there is increased apoptosis in cells present in lesions caused by these bacteria. Since these bacteria produce butyrate as part of their metabolism, this substance is an interesting candidate for the modulation of macrophage apoptosis by bacteria at the site of lesion.

In the present study, we show that butyrate is capable of inducing apoptosis in mouse peritoneal macrophages in a doseand time-dependent manner. We also show that the mechanism of induction of apoptosis seems to be dependent on caspases, especially caspase-3, but does not appear to involve the action of tumor necrosis factor $\alpha$ (TNF- $\alpha$ ) or nitric oxide (NO).

\section{Material and Methods}

\section{Macrophage culture}

C57BL/6 mice, 4 to 6 weeks old, were provided by the animal house of the Centro de Pesquisas René Rachou, FIOCRUZ (Belo Horizonte, MG, Brazil), kept in collective cages with free access to commercial chow (Nuvital, Curitiba, PR, Brazil) and water. In order to obtain inflammatory macrophages, mice were injected intraperitoneally with 2 $\mathrm{ml}$ of $3 \%$ thioglycolate medium and peritoneal exudate cells were collected by lavage with RPMI 1640 medium (Gibco BRL, Gaithersburg, MD, USA) 4 days after injection. The cells $\left(1 \times 10^{6} / \mathrm{ml}\right)$ were cultured in $5 \mathrm{ml}$ polypropylene tubes in RPMI 1640 medium containing $100 \mathrm{U} / \mathrm{ml}$ penicillin, $100 \mu \mathrm{g} / \mathrm{ml}$ streptomycin, $2 \mathrm{mM}$ glutamine, and $10 \%$ fetal calf serum that had been inactivated for $30 \mathrm{~min}$ at $56^{\circ} \mathrm{C}$. Polypropylene tubes were 
used in some experiments since macrophages do not attach to these tubes, so that all cells can be collected and analyzed rather than only detached cells. The solution of butyric acid (Sigma, St. Louis, MO, USA) was diluted in RPMI 1640 medium and the $\mathrm{pH}$ adjusted to 7.2 with sodium hydroxide. $\mathrm{Bu}$ tyrate was added to the cultures to final concentrations of $0,1,2,4$ and $8 \mathrm{mM}$, as indicated in each experiment. Lipopolysaccharide (LPS; Sigma) was diluted in RPMI medium and added to the cultures at a concentration of $1 \mu \mathrm{g} / \mathrm{ml}$ at the time of butyrate addition. Cultures were incubated at $37^{\circ} \mathrm{C}$ in a moist atmosphere of $5 \% \mathrm{CO}_{2}$ for the indicated periods of time.

\section{Determination of cell viability}

After treatment with butyrate or butyrate plus LPS, cells were stained with Trypan blue and the number of live (cells that exclude Trypan blue) or dead (cells that stain with Trypan blue) cells was counted in a Neubauer chamber. The values were adjusted to percentages. The MTT (3-(4,5-dimethyl-2-thiazolyl)-2,5-diphenyl tetrazolium bromide) (Sigma) assay was performed as described by Jacobson et al. (17). Cells ( $1 \mathrm{x}$ $10^{5}$ ) were cultured on 96-well plates with or without different concentrations of butyrate in the presence or absence of LPS. After 24-h treatment, $10 \mu \mathrm{l}$ of a $5 \mathrm{mg} / \mathrm{ml}$ MTT solution was added to each well. After $4 \mathrm{~h}$ of incubation at $37^{\circ} \mathrm{C}$ the formazan precipitates were solubilized by the addition of $100 \mu$ of an acid solution of SDS (10\% SDS in $0.01 \mathrm{M}$ $\mathrm{HCl})$ and the plate was incubated overnight at $37^{\circ} \mathrm{C}$. Absorbance at $570 \mathrm{~nm}$ was determined with a spectrophotometric microplate reader (SpectraMAX plus, Molecular Devices).

\section{DNA isolation}

Peritoneal cells $\left(4 \times 10^{6}\right)$ were incubated with butyrate in the presence or absence of
LPS for the indicated times. The cells were collected, washed twice with PBS and resuspended in hypotonic lysis buffer $(0.2 \%$ Triton X-100, $10 \mathrm{mM}$ Tris, $1 \mathrm{mM}$ EDTA, $\mathrm{pH}$ $8.0)$. After 10-min incubation at room temperature $\left(25^{\circ} \mathrm{C}\right)$ the cells were centrifuged at $14,000 \mathrm{rpm}$ for $15 \mathrm{~min}$. The supernatant was used for DNA electrophoresis.

\section{Electrophoresis}

The supernatant obtained as described for DNA isolation was treated with an equal volume of absolute isopropyl alcohol and $0.5 \mathrm{M} \mathrm{NaCl}$ and stored at $-20^{\circ} \mathrm{C}$ overnight. The samples were then centrifuged at 14,000 rpm for $15 \mathrm{~min}$ and the pellet was washed with $100 \mu$ of $70 \%$ ethanol and resuspended in $25 \mu \mathrm{l}$ TE solution [ $10 \mathrm{mM}$ Tris- $\mathrm{HCl}, 1 \mathrm{mM}$ EDTA, pH 7.4, plus $5 \mu \mathrm{l}$ of loading buffer (50\% glycerol, $1 \mathrm{X}$ Tris-acetate-EDTA, 10\% saturated bromophenol blue, and $1 \%$ xylene cyanol)]. Samples were subjected to horizontal gel electrophoresis on $1.5 \%$ agarose gel containing $0.71 \mu$ g ethidium bromide per $\mathrm{ml}$. The cells were photographed under UV transillumination using Nucleovision equipment (Nucleotech).

\section{Flow cytometry analysis}

The percentage of cells that underwent necrosis or apoptosis was determined using simultaneous annexin-V-FITC (Pharmingen, San Diego, CA, USA) and propidium iodide (Sigma) staining. The assay was performed according to manufacturer instructions. Peritoneal cells $\left(1 \times 10^{6}\right)$ incubated with butyrate for $24 \mathrm{~h}$ in the presence or absence of LPS were collected and washed twice with cold PBS. The cells were then resuspended in annexin-V-binding buffer (10 mM HEPES/ $\mathrm{NaOH}, \mathrm{pH} 7.4,140 \mathrm{mM} \mathrm{NaCl}$, and $2.5 \mathrm{mM}$ $\mathrm{CaCl}_{2}$ ) and $1 \times 10^{5}$ cells were transferred to 5-ml polystyrene tubes (Becton Dickinson, New Jersey, NJ, USA). Annexin-V-biotin (5 $\mu \mathrm{l})$ was added and the cells were incubated 
for $15 \mathrm{~min}$ at room temperature $\left(25^{\circ} \mathrm{C}\right)$. The cells were washed once with annexin-Vbinding buffer and $100 \mu \mathrm{l}$ of a $50 \mu \mathrm{g} / \mathrm{ml}$ streptavidin-FITC solution plus $5 \mu \mathrm{l}$ propidium iodide were added. The cells were incubated for $15 \mathrm{~min}$ and analyzed by flow cytometry within $1 \mathrm{~h}$ using FACSAdvantage equipment (Becton Dickinson).

The percentage of cells in the peritoneal cell population consisting of macrophages was determined by flow cytometry. After treatment with or without $4 \mathrm{mM}$ butyrate for $24 \mathrm{~h}$, peritoneal cells $\left(1 \times 10^{6}\right)$ were washed twice with PBS. Cells were preincubated with anti-Fc receptor antibody and then stained with FITC-labeled Mac-1 (Pharmingen), a cell marker specific for granulocytes, macrophages and natural killer cells or with FITC-labeled Mac-3 (Pharmingen), a cell marker specific for activated macrophages (including thioglycolate-elicited peritoneal macrophages) for $15 \mathrm{~min}$ and washed twice with PBS. The cells were then incubated with phycoerythrin-labeled annexin-V (Pharmingen) (a marker specific for apoptosis) for 15 min. Cells were washed twice in PBS and analyzed by flow cytometry using FACS Advantage equipment (Becton Dickinson).

Hypodiploid DNA was measured by the method described by Nicoletti et al. (18). After treatment with the reagents, cells (1 x $10^{6}$ ) were centrifuged at $1200 \mathrm{rpm}$ for 10 min and washed twice with cold PBS. The cell pellet was gently resuspended in $1 \mathrm{ml}$ hypotonic fluorochrome solution $(50 \mu \mathrm{g} / \mathrm{ml}$ propidium iodide in $0.1 \%$ sodium citrate plus $0.1 \%$ Triton $\mathrm{X}$-100) in $5 \mathrm{ml}$ polypropylene tubes (Becton Dickinson). The tubes were left to stand at $4^{\circ} \mathrm{C}$ in the dark overnight. The cells were analyzed by flow cytometry using FACSAdvantage equipment (Becton Dickinson).

\section{Measurement of caspase-3 activity}

Caspase-3 activity was measured using the colorimetric CaspACE assay system (Pro- mega, Madison, WI, USA) following instructions provided by the manufacturer. After treatment with butyrate or butyrate plus LPS, cells $\left(1 \times 10^{7}\right)$ were washed twice in ice-cold PBS and resuspended in cell lysis buffer (provided by the manufacturer) at a concentration of $10^{8}$ cells $/ \mathrm{ml}$. The cells were lysed by four cycles of freezing and thawing and incubated on ice for $15 \mathrm{~min}$. The cell lysates were centrifuged at 15,000 $\mathrm{g}$ for 20 min at $4^{\circ} \mathrm{C}$ and the supernatant fraction was collected and stored at $-70^{\circ} \mathrm{C}$ until the time for caspase activity determination. To measure caspase activity, the concentration of protein in each sample was determined by the method of Lowry et al. (19) for protein quantitation. One hundred $\mu \mathrm{g}$ of total protein (in a volume of up to $20 \mu \mathrm{l}$ ) from each sample was added to each well of a 96-well plate. Then $32 \mu \mathrm{l}$ of caspase assay buffer (provided by the manufacturer), $2 \mu \mathrm{DMSO}$ and $10 \mu \mathrm{l}$ of a $100 \mathrm{mM}$ DTT solution were added to each well. The final volume was adjusted to $98 \mu \mathrm{l}$ and $2 \mu \mathrm{l}$ of the caspase- 3 substrate DEVD-pNA was added to the reaction. The plate was incubated at $37^{\circ} \mathrm{C}$ overnight. Absorbance at $405 \mathrm{~nm}$ was determined with a spectrophotometric microplate reader (SpectraMAX plus, Molecular Devices).

\section{Determination of TNF- $\alpha$ and nitrite levels in the supernatants of macrophage cultures}

TNF- $\alpha$ was quantified with an ELISA kit (Duoset kit, Genzyme Diagnostics, Cambridge, MA, USA). Nitrite concentrations in culture supernatants were assayed by the Griess reaction (20). Plates were read at 550 $\mathrm{nm}$ and $\mathrm{NO}_{2}$ concentration was determined with reference to a standard curve using sodium nitrite in culture media.

The caspase inhibition assay was performed using the pancaspase inhibitor $\mathrm{z}$ VAD-FMK. Cells were preincubated with the caspase inhibitor at a concentration of 50 $\mu \mathrm{M}$ for $45 \mathrm{~min}$. Butyrate or butyrate plus 
LPS was then added and the cells were incubated for different periods of time and cell viability was determined by Trypan blue exclusion.

\section{Statistical analysis}

In some experiments apoptosis was a uniform phenomenon and differences were evident without statistical analysis. All other data were analyzed by the Student $t$-test with a $5 \%$ confidence interval.

\section{Results}

Butyrate decreases peritoneal cell viability in a dose- and time-dependent manner. To determine the effects of butyrate on macrophage viability, the cells were treated with different concentrations of butyrate in the presence or absence of LPS. Butyrate decreased cell viability in a dose-dependent fashion as shown by the MTT assay (Figure 1A). A decrease was observed at butyrate concentrations as low as $1 \mathrm{mM}$. LPS treat-
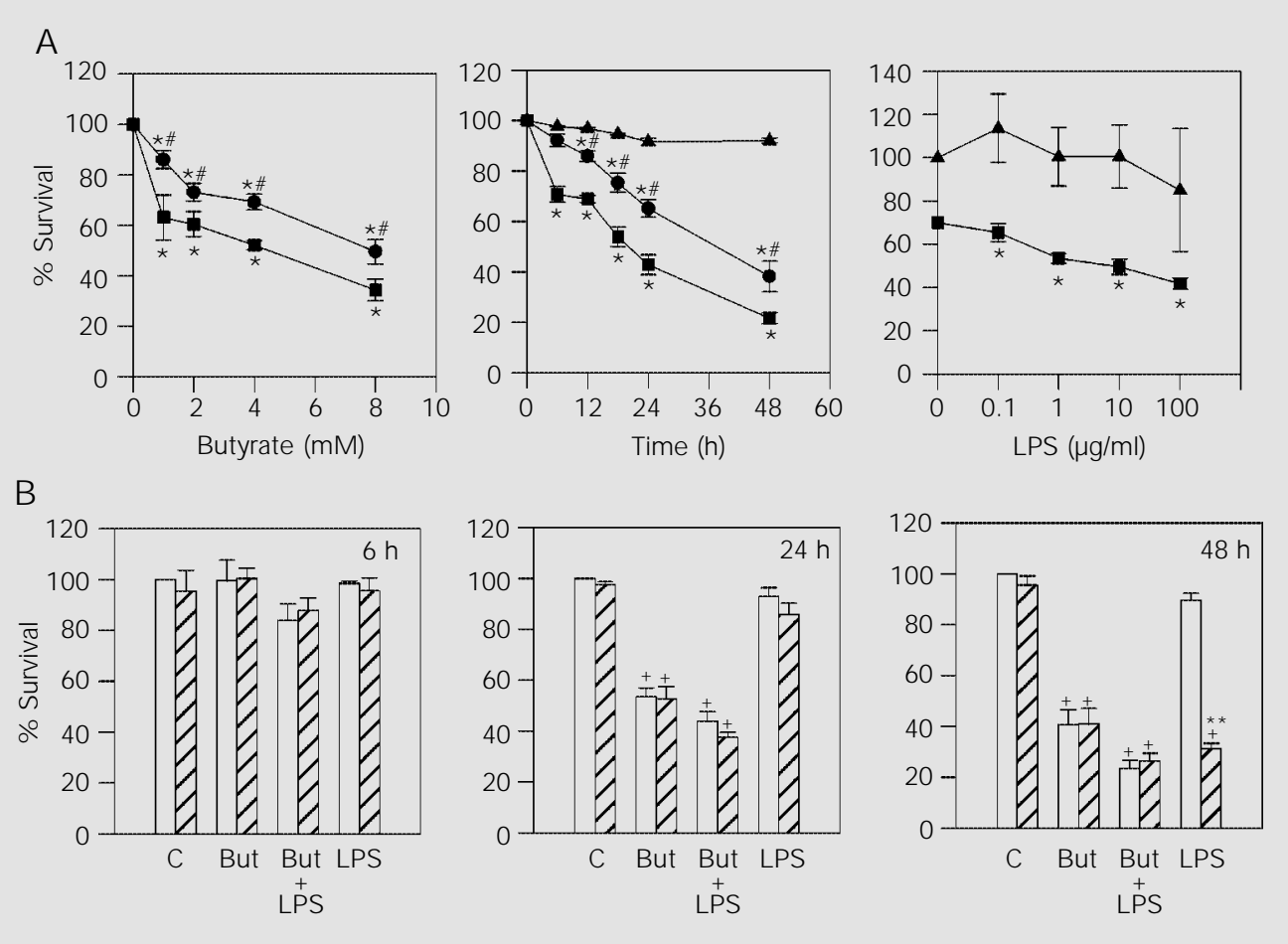

Figure 1. Cell viability determined in the MTT assay. A, Dose-dependent effect of butyrate on cell viability (left panel). Peritoneal macrophages were cultured with the indicated concentration of butyrate in the presence (squares) or absence (circles) of $1 \mu \mathrm{g} / \mathrm{ml}$ LPS for $24 \mathrm{~h}$. Time-dependent effect of butyrate on cell viability (middle panel). Peritoneal macrophages were treated with $4 \mathrm{mM}$ butyrate in the presence (squares) or absence (circles) of $1 \mu \mathrm{g} / \mathrm{ml}$ LPS for different periods of time. Triangles represent untreated control cells (middle panel). Effect of different concentrations of LPS with (squares) or without (triangles) butyrate on macrophage viability (right panel). Peritoneal macrophages were cultured with or without $4 \mathrm{mM}$ butyrate in the presence of $0,0.1,1,10 \mathrm{or} 100 \mu \mathrm{g} / \mathrm{ml}$ LPS. B, Effect of IFN- $\gamma$ on LPS- or butyrate-induced cell death. Peritoneal macrophages were treated with $4 \mathrm{mM}$ butyrate, $4 \mathrm{mM}$ butyrate plus $1 \mu \mathrm{g} / \mathrm{ml}$ LPS or $1 \mu \mathrm{g} / \mathrm{ml}$ LPS alone in the presence (hatched bar) or absence (open bar) of $50 \mathrm{IU} / \mathrm{ml} \mathrm{IFN}-\gamma$ for 6,24 and $48 \mathrm{~h}$. Control represents untreated cells. Results are reported as the mean \pm SEM of five (Figure $1 \mathrm{~A}$ ) and three (Figure 1B) different experiments with duplicate cultures. $* \mathrm{P}<0.05$ compared to the corresponding negative controls without butyrate. ${ }^{\#} \mathrm{P}<0.05$ compared to the butyrate plus LPS-treated group at each corresponding butyrate concentration or time point. $+\mathrm{P}<0.05$ compared to the corresponding negative controls with or without IFN- $\gamma$. ${ }^{*} \mathrm{P}<0.05$ compared to the group treated with LPS alone (Student t-test). C, control; But, butyrate. 
Figure 2. A, Effect of butyrate with or without LPS on DNA fragmentation. Agarose gel electrophoresis of DNA extracted from mouse peritoneal macrophages treated with $4 \mathrm{mM}$ butyrate or butyrate plus $1 \mu \mathrm{g} / \mathrm{ml}$ LPS for $24 \mathrm{~h}$. MW, molecular weight markers; C, control; But, butyrate. The figure corresponds to one of three experiments yielding similar results. B, Flow cytometry analysis of the DNA contents of butyrate or butyrate plus LPS-treated cells. Peritoneal macrophages were cultured with or without $4 \mathrm{mM}$ butyrate in the presence or absence of 1 $\mu \mathrm{g} / \mathrm{ml}$ LPS for $24 \mathrm{~h}$. Macrophages were stained with propidium iodide and DNA content was analyzed by flow cytometry. Cells containing subdiploid nuclei are apoptotic cells. Debris were excluded according to forward and side scatter characteristics. The right peak shows the percentage of cells with normal diploid DNA and the left peak shows the percentage of apoptotic cells with subdiploid DNA. The experiment shown is one of a total of five independent experiments with similar results.

ment at $1 \mu \mathrm{g} / \mathrm{ml}$ increased the effect of butyrate. The effects of butyrate occurred in a time-dependent manner. As shown in Figure 1A (middle panel), macrophages treated with $4 \mathrm{mM}$ butyrate alone or butyrate plus $1 \mu \mathrm{g} /$

A

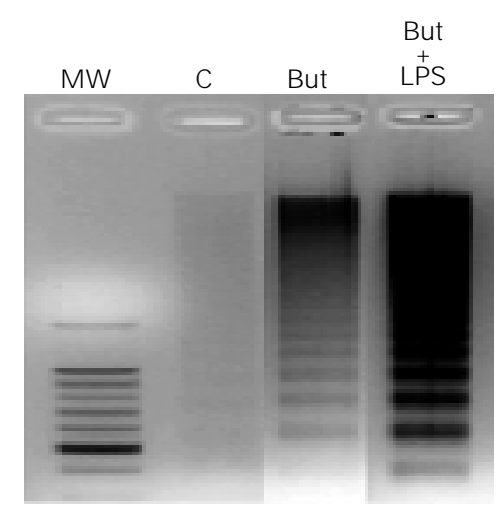

B
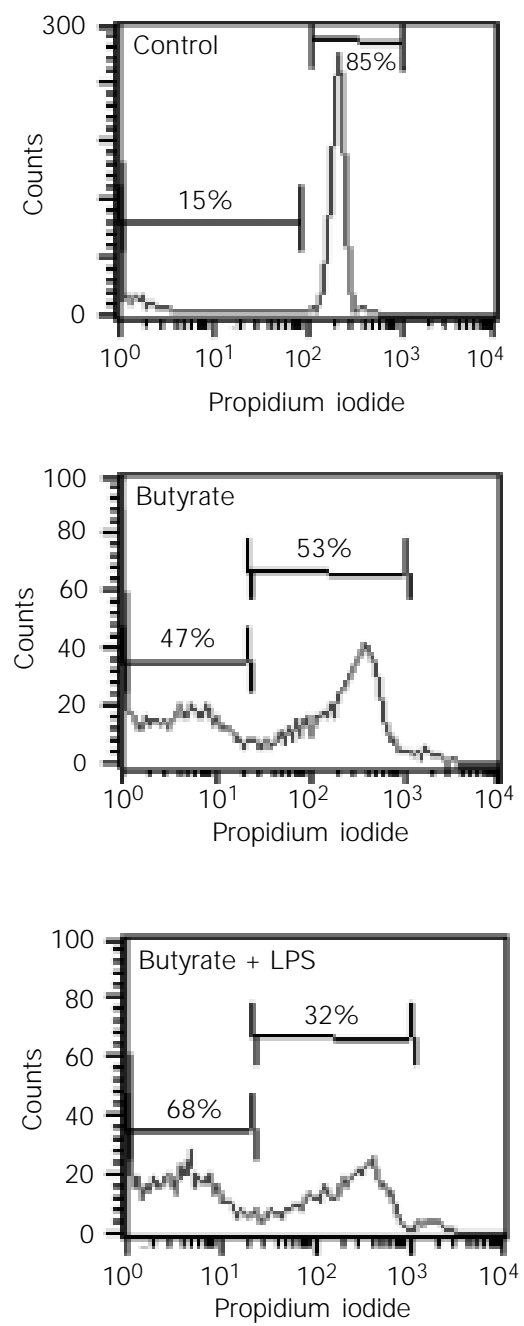

ml LPS for different periods of time presented diminished cell viability already at $12 \mathrm{~h}$ after treatment. Treatment with butyrate plus LPS decreased cell viability $6 \mathrm{~h}$ after the beginning of treatment and this effect was stronger than that seen with butyrate alone at all time points. The effect was maximal at $48 \mathrm{~h}$ post-treatment with butyrate combined with LPS. To study the effect of LPS alone on macrophage viability, the cells were treated with different concentrations of LPS for $24 \mathrm{~h}$. Using both the MTT and Trypan blue exclusion assays (data not shown), LPS at concentrations as high as $100 \mu \mathrm{g} / \mathrm{ml}$ was not able to induce cell death in peritoneal macrophages (Figure 1A, right panel). When $4 \mathrm{mM}$ butyrate was added together with LPS, a significant decrease in cell viability was observed at LPS concentrations of 1, 10 and $100 \mu \mathrm{g} / \mathrm{ml}$.

Previous studies have shown that the combination of LPS and interferon gamma (IFN$\gamma)$ can strongly induce apoptosis in macrophages. To confirm these data and also to test if IFN- $\gamma$ would also have any effects on butyrate-induced apoptosis, we treated peritoneal macrophages with $4 \mathrm{mM}$ butyrate alone or with $1 \mu \mathrm{g} / \mathrm{ml}$ LPS in the absence or presence of IFN- $\gamma(50 \mathrm{IU} / \mathrm{ml})$ for 6,24 and $48 \mathrm{~h}$. After 6-h treatment, there was no significant decrease in cell survival (Figure 1B). As shown previously by our results, butyrate caused a significant decrease in cell survival after 24 and $48 \mathrm{~h}$ of incubation and LPS augmented this effect. IFN- $\gamma$ had no effect on butyrate alone or butyrate plus LPS induction of cell death. As mentioned above, treatment with LPS alone was unable to induce cell death, but when IFN- $\gamma$ was added, a strong decrease in cell survival was seen after $48 \mathrm{~h}$ of treatment (Figure 1B, right panel).

\section{Butyrate induces apoptosis in peritoneal cells}

To determine if the increase in cell death induced by butyrate treatment was apopto- 
sis, we studied DNA fragmentation in macrophages treated with $4 \mathrm{mM}$ butyrate with or without LPS for $24 \mathrm{~h}$. DNA fragmentation was increased in cells treated with butyrate and butyrate plus LPS as compared to untreated control cells (Figure 2A). Cells treated with butyrate plus LPS showed an additional increase in DNA fragmentation when compared to cells treated with butyrate alone (Figure 2A).

To quantify macrophage apoptosis caused by butyrate or butyrate plus LPS, the percentage of hypodiploid nuclei (characteristic for apoptotic cell populations) was measured by flow cytometry. After 24-h treatment with butyrate, $58 \%$ of the cells exhibited subdiploid nuclei, in contrast with control cells, that showed 19\% apoptotic cells. The addition of LPS to butyrate-treated cells significantly increased the number of subdiploid nuclei $(72 \%)$ as shown in Figure 2B.

To further examine the effect of butyrate alone or combined with LPS on induction of apoptosis in macrophages we analyzed the early apoptosis event by annexin-V-FITC and propidium iodide staining. Macrophages were treated with $4 \mathrm{mM}$ butyrate alone or with LPS for $24 \mathrm{~h}$. Cells were then stained with annexin- $\mathrm{V}$ and propidium iodide and analyzed by flow cytometry. After 24-h culture, $5.38 \pm 0.5 \%$ of untreated control cells were in an early stage of apoptosis and 1.98 $\pm 0.33 \%$ were late apoptotic or necrotic (Figure $3 \mathrm{~A}$ ). After treatment with butyrate alone, $43.79 \pm 3.74 \%$ of the cells were in an early
A

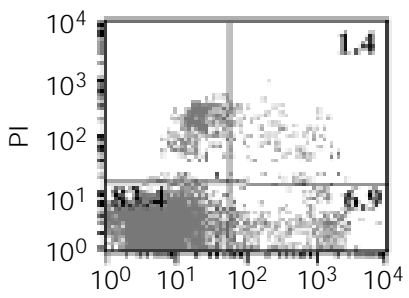

Butyrate

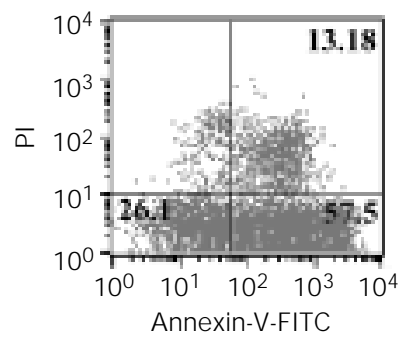

Butyrate + LPS
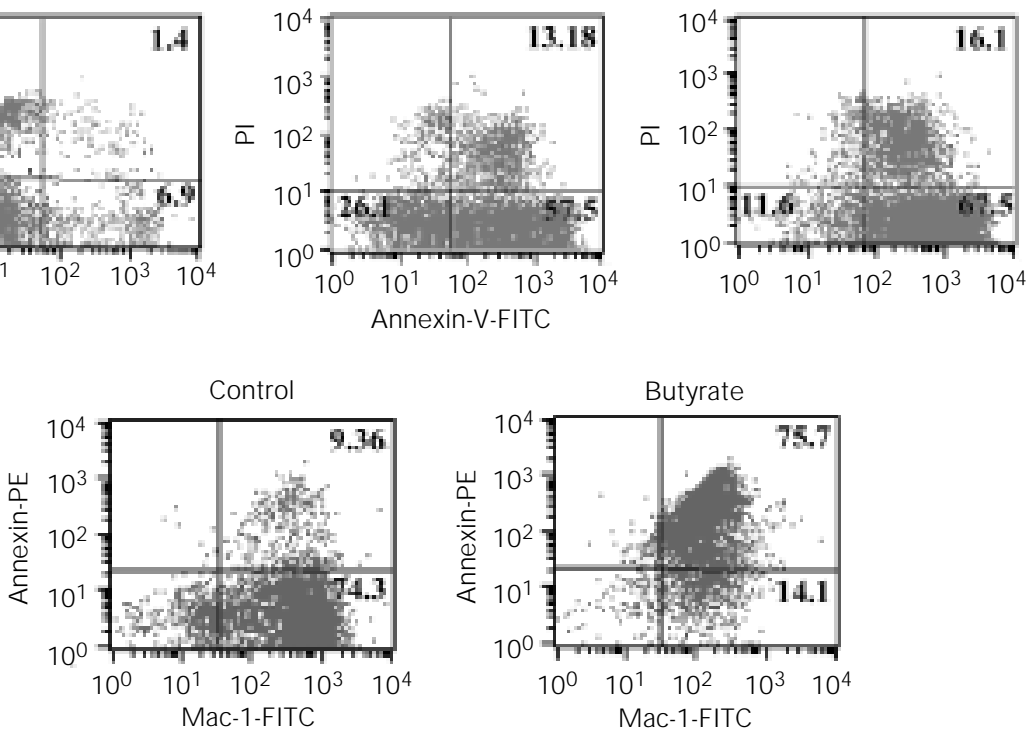

Control

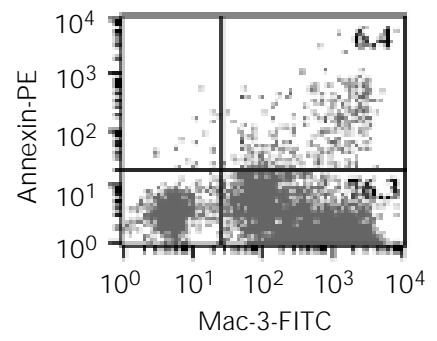

Butyrate
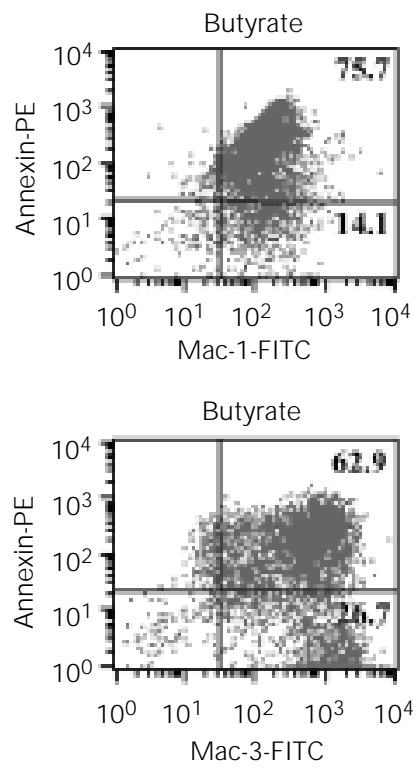

Figure 3. A, Butyrate induces apoptosis in peritoneal macrophages. Cells were treated with $4 \mathrm{mM}$ butyrate in the absence or presence of $1 \mu \mathrm{g} / \mathrm{ml}$ LPS for 24 h. Cells were double stained with annexin-V-FITC and propidium iodide $(\mathrm{PI})$ and analyzed by flow cytometry. Annexin- $\mathrm{V}^{-}, \mathrm{PI}^{-}$ cells are live cells, annexin- $\mathrm{V}^{+}$, $\mathrm{Pl}^{-}$cells are early apoptotic cells, and annexin- $\mathrm{V}^{+}, \mathrm{PI}^{+}$cells are late apoptotic or necrotic cells. Data represent one of four different experiments with similar results. B, Flow cytometry analysis of the peritoneal cell population. Peritoneal cells were double stained with FITC-labeled Mac-1 or FITC-labeled Mac-3 and phycoerythrin (PE)-labeled annexin$V$ after treatment with $4 \mathrm{mM}$ butyrate for $24 \mathrm{~h}$. Data represent one of three different experiments with similar results. 
stage of apoptosis and $12.29 \pm 1.61 \%$ were in a late stage of apoptosis or already dead. These numbers were significantly higher than those seen in untreated control cells $(\mathrm{P}<0.05)$. The addition of LPS significantly increased the number of early and late apoptotic cells $(65.57 \pm 4.39 \%$ and $31.26 \pm 2.79 \%$, respectively) when compared to butyrate alone and to untreated control cells $(\mathrm{P}<0.05)$.

To analyze the population of peritoneal cells that were undergoing apoptosis, we double stained untreated control or butyratetreated cells with phycoerythrin-labeled annexin-V and with FITC-labeled Mac-1 or Mac-3 that are cellular markers specific for monocytes/macrophages. Figure 3B shows that most untreated and butyrate-treated cells were positive for Mac-1 and Mac-3, confirming that the majority of apoptotic peritoneal cells were macrophages.

Figure 4. Caspase-3 is involved in peritoneal macrophage apoptosis. A, Macrophages were cultured without butyrate (filled bar) or with $4 \mathrm{mM}$ butyrate (open bar) in the absence or presence of LPS (hatched bar) $(1 \mu \mathrm{g} / \mathrm{ml})$ for 6 or $24 \mathrm{~h}$. Cell lysates were analyzed for the presence of caspase-3 activity using a colorimetric substrate (DEVD-pNA). Results are reported as the mean \pm SEM of three different experiments with duplicate samples. Different letters indicate significantly different values at each time point $(P<0.05)$. B, Peritoneal macrophages were cultured with

A

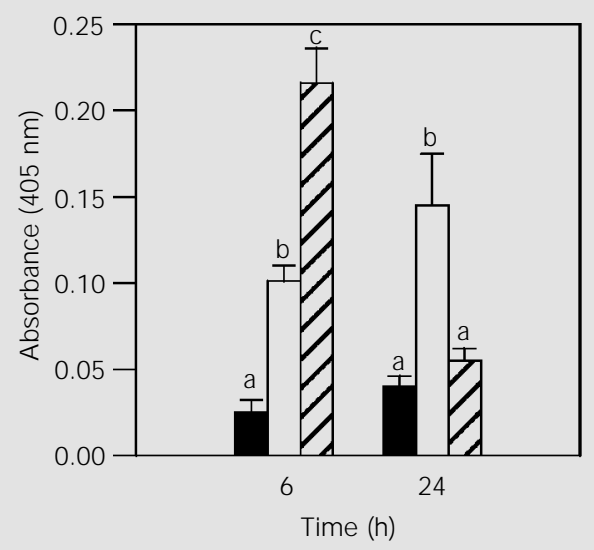

B

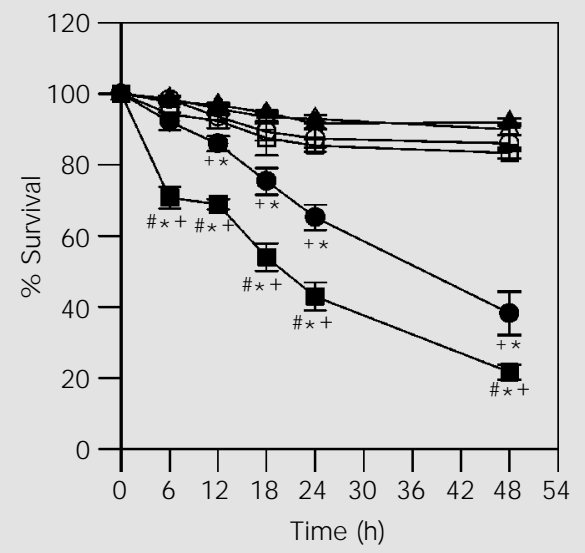

(circles) or without (triangles) 4 $\mathrm{mM}$ butyrate in the presence (squares) or absence of $1 \mu \mathrm{g} / \mathrm{ml}$ LPS and with (open symbols) or without (filled symbols) the pancaspase inhibitor z-VAD-FMK for different periods of time. Cell viability was determined by Trypan blue exclusion. Results are reported as the mean \pm SEM of five different experiments with duplicate samples. $* \mathrm{P}<0.05$ compared to the corresponding negative controls without butyrate. $\# \mathrm{P}<0.05$ compared to the butyrate plus LPS-treated group at each time point. $+\mathrm{P}<0.05$ compared to the corresponding group treated with the pancaspase inhibitor, $z$-VAD-FMK (Student $t$-test).

Table 1. Determination of tumor necrosis factor $\alpha(\mathrm{TNF}-\alpha)$ and nitric oxide concentrations in the culture supematants from macrophages treated with butyrate $(4 \mathrm{mM})$ and/or lipopolysaccharide (LPS) $(1 \mu \mathrm{g} / \mathrm{ml})$ in the presence or absence of interferon $\gamma(\mathrm{IFN}-\gamma)(50 \mathrm{IU} / \mathrm{ml})$.

\begin{tabular}{|c|c|c|c|c|c|c|}
\hline & \multicolumn{3}{|c|}{ Without IFN- $\gamma$} & \multicolumn{3}{|c|}{ With IFN- $\gamma$} \\
\hline & $6 \mathrm{~h}$ & $24 \mathrm{~h}$ & $48 \mathrm{~h}$ & $6 \mathrm{~h}$ & $24 \mathrm{~h}$ & $48 \mathrm{~h}$ \\
\hline \multicolumn{7}{|l|}{ TNF- $\alpha(p g / m l)$} \\
\hline Control & $282.4 \pm 36.1$ & $372.2 \pm 12.9$ & ND & $253.0 \pm 45.43$ & $1024.6 \pm 72.5$ & ND \\
\hline Butyrate & $466.4 \pm 19.6$ & $448.7 \pm 32.4$ & ND & $744.4 \pm 14.82$ & $1226.6 \pm 45.0$ & ND \\
\hline Butyrate + LPS & $2435.2 \pm 120.3$ & $1550.9 \pm 199.4$ & ND & $2066.4 \pm 110.41$ & $2842.0 \pm 98.5$ & ND \\
\hline LPS & $2848.7 \pm 58.4$ & $2607.0 \pm 92.7$ & ND & $2529.4 \pm 856.5$ & $4012.3 \pm 181.8$ & ND \\
\hline \multicolumn{7}{|l|}{ Nitric oxide $(\mu \mathrm{M})$} \\
\hline Control & $2.78 \pm 0.16$ & $3.66 \pm 0.14$ & $3.87 \pm 0.09$ & $6.20 \pm 0.00$ & $19.20 \pm 2.00$ & $18.20 \pm 1.53$ \\
\hline Butyrate & $2.30 \pm 0.21$ & $3.62 \pm 0.72$ & $3.14 \pm 0.25$ & $3.87 \pm 0.33$ & $10.20 \pm 0.58$ & $18.20 \pm 1.15$ \\
\hline Butyrate + LPS & $2.97 \pm 0.16$ & $2.60 \pm 0.50$ & $3.54 \pm 0.13$ & $3.87 \pm 0.67$ & $10.87 \pm 0.33$ & $18.53 \pm 0.67$ \\
\hline LPS & $3.14 \pm 0.09$ & $27.17 \pm 3.15$ & $33.38 \pm 1.19$ & $7.87 \pm 0.67$ & $40.87 \pm 1.45$ & $61.87 \pm 1.45$ \\
\hline
\end{tabular}

Results are reported as the mean \pm SEM of triplicate wells. ND, not determined. 


\section{Caspase- 3 is involved in peritoneal macrophage apoptosis}

The requirement for caspase- 3 activity in butyrate-induced apoptosis was determined by its capacity to cleave its substrate AcDEVD-pNA. Caspase-3 activity was increased during apoptosis induced by butyrate treatment (Figure 4A). Cells treated with butyrate and LPS showed a significant increase in caspase- 3 activity when compared to untreated control cells and also to butyrate-treated cells after 6-h treatment. However, caspase- 3 activity was decreased in these cells after 24-h treatment, reaching control levels (Figure 4A). This finding may be explained by the stronger and faster apoptotic effect seen in butyrate plus LPS-treated cells. In agreement with this hypothesis, cell viability and flow cytometry experiments (Figures 1,2 and 3) showed that a large amount of butyrate plus LPS-treated cells were not viable after $24-\mathrm{h}$ treatment. Thus, we suggest that activation of caspase- 3 initiated earlier in cells treated with butyrate and LPS, which underwent apoptosis and died earlier, and caspase activity became undetectable at $24 \mathrm{~h}$ post-stimulation. To confirm the importance of the caspase cascade in butyrate-induced apoptosis, cells were treated concomitantly with butyrate (with or with- out LPS) and the pancaspase inhibitor $\mathrm{z}$ VAD-FMK for different periods of time. The results showed that the caspase inhibitor was capable of inhibiting the effect of butyrate or of butyrate plus LPS, indicating the major role of caspases in butyrate-induced apoptosis in these cells (Figure 4B).

\section{Apoptosis induced by butyrate in peritoneal macrophages is not dependent on nitric oxide or TNF- $\alpha$}

TNF and NO have been shown to be important mediators of apoptosis in cells treated with LPS and IFN- $\gamma$. To investigate the involvement of TNF and NO in butyrateinduced apoptosis, we treated peritoneal macrophages with $4 \mathrm{mM}$ butyrate alone or with LPS in the presence or absence of IFN- $\gamma$ for 6,24 or $48 \mathrm{~h}$ and measured the production of TNF- $\alpha$ and nitrite in the supernatant of the macrophage cultures (Table 1).

After 6 and $24 \mathrm{~h}$ of treatment a significant production of TNF- $\alpha$ was observed in macrophages exposed to LPS but not to butyrate. Cells treated with LPS alone showed a significant production of NO 24 and $48 \mathrm{~h}$ after stimulation. Nitrite production was higher at both times when IFN- $\gamma$ was added together with LPS. However, in all cells treated with butyrate, no matter if LPS or IFN- $\gamma$ were

Table 2. Percent survival of macrophages from different mouse strains treated with butyrate $(4 \mathrm{mM})$ or lipopolysaccharide (LPS) $(1 \mu \mathrm{g} / \mathrm{ml})$ plus interferon $\gamma(\mathrm{IFN}-\gamma)(50 \mathrm{IU} / \mathrm{ml})$ for 24 or $48 \mathrm{~h}$.

\begin{tabular}{lccccc}
\hline & \multicolumn{2}{c}{$24 \mathrm{~h}$} & & \multicolumn{2}{c}{$48 \mathrm{~h}$} \\
\cline { 2 - 3 } \cline { 5 - 6 } & \multicolumn{1}{c}{ Butyrate } & LPS + IFN- $\gamma$ & & Butyrate & LPS + IFN- $\gamma$ \\
\hline C57BL/6 & $75.05 \pm 4.96^{*}$ & $78.25 \pm 2.36^{*}$ & & $64.38 \pm 2.76^{*}$ & $56.38 \pm 7.10^{*}$ \\
iNOS-- & $63.95 \pm 4.00^{*}$ & $93.99 \pm 3.14^{+}$ & & $49.59 \pm 3.37^{*}$ & $79.95 \pm 0.59^{*+}$ \\
TNFR1- & $80.22 \pm 4.43^{*}$ & $94.55 \pm 1.88^{+}$ & & $67.40 \pm 1.58^{*}$ & $81.21 \pm 2.21^{*+}$ \\
IRF1- & $65.12 \pm 5.17^{*}$ & $89.17 \pm 4.73^{+}$ & & $64.84 \pm 1.53^{*}$ & $102.90 \pm 5.94^{+}$
\end{tabular}

Results are reported as the mean \pm SEM of four different experiments and are expressed as percent survival compared to the untreated control group $(100 \%)$ from the same strain.

$* \mathrm{P}<0.05$ compared to the corresponding untreated control group;

$+\mathrm{P}<0.05$ compared to the corresponding group treated with butyrate alone (Student t-test).

iNOS ${ }^{-1}$, TNFR1--, IRF-1-1-: mice lacking genes for inducible nitric oxide synthase, type I receptor for tumor necrosis factor and interferon regulatory factor 1 , respectively. 
added, NO production was prevented and remained at basal levels or even lower during 24 or $48 \mathrm{~h}$ of treatment.

To investigate the involvement of the autocrine production of TNF and NO in butyrate-induced apoptosis, we evaluated the responsiveness of macrophages derived from mice lacking genes for inducible NO synthase $\left(\mathrm{iNOS}^{-/}\right)$, type I receptor for TNF $\left(\mathrm{TNFR}^{-/}\right)$, and interferon regulatory factor 1 (IRF-1 ${ }^{-/}$) with $4 \mathrm{mM}$ butyrate or with LPS plus IFN- $\gamma$ for 24 or $48 \mathrm{~h}$. Table 2 shows that the viability of macrophages from all the knockout mice was significantly decreased after treatment with butyrate for 24 or $48 \mathrm{~h}$ when compared to untreated cells. In contrast, apoptosis in macrophages stimulated with LPS plus IFN- $\gamma$ was mostly reversed in macrophages from IRF- $1^{-/}$, and partially reversed in macrophages from $\mathrm{iNOS}^{-/}$and $\mathrm{TNFR}^{-/-}$mice. These results are consistent with the hypothesis that TNF and NO are involved in the apoptosis of macrophages exposed to LPS, but not to butyrate.

\section{Discussion}

Apoptosis is a process of programmed cell death important in many physiological functions and in the pathogenesis of a variety of diseases. The processes and molecules that can elicit activation of the apoptotic program are diverse. In this study we show that butyrate is able to induce apoptosis in peritoneal macrophages in a dose- and timedependent manner as demonstrated by the results of cell viability, flow cytometric analysis of annexin- $\mathrm{V}$, DNA ladder pattern and determination of hypodiploid DNA. This process appears to be dependent on caspase3 but, unlike macrophage apoptosis induced by LPS, is independent of macrophage priming with IFN- $\gamma$ and autocrine synthesis of TNF- $\alpha$ and NO.

The physiologic onset of apoptosis is strictly regulated by ligand receptor systems such as Fas ligand/Fas and TNF/TNFR1
$(21,22)$. LPS can induce macrophage production of TNF- $\alpha$ that is an important mediator of the apoptosis-enhancing effect triggered by LPS $(23,24)$. To initiate apoptosis, TNF binds to TNFR1 and induces intracellular signals leading to a caspase cascade that will result in the transcription of genes controlling the cell cycle and initiation of apoptosis $(25,26)$. A recent study by Xaus et al. (26) showed that LPS-induced apoptosis results from two independent mechanisms: first and predominantly, through the autocrine secretion of TNF- $\alpha$ (early apoptotic events), and second, through the production of NO (late phase of apoptosis).

In our experiments, in the absence of butyrate, LPS concentrations as high as 100 $\mu \mathrm{g} / \mathrm{ml}$ did not induce apoptosis in inflammatory macrophages. When IFN- $\gamma$ was added concomitantly to LPS, significant cell death was seen after $48 \mathrm{~h}$ of macrophage stimulation. Our study is in agreement with others $(27,28)$ showing that LPS plus IFN- $\gamma$ triggers apoptosis in peritoneal macrophages. IRF-1 is a transcription factor induced by IFN- $\gamma$ and is responsible for the activation of many genes induced by this cytokine. Consistent with the requirement of IFN- $\gamma$ priming, our experiments show that apoptosis induced by IFN- $\gamma$ and LPS was completely abolished in macrophages from IRF- $1^{-/}$. Our study confirmed the results showing the dependency of autocrine TNF- $\alpha$ and NO synthesis $(26,29)$ on LPS-induced apoptosis, since we observed a partial reduction of apoptosis in macrophages from TNFR $1^{-/}$and iNOS $^{-/-}$treated with IFN- $\gamma$ and LPS. In contrast, the levels of apoptosis were not affected in macrophages from IRF-1 $1^{-/-}$, TNFR $1^{-}$ - and $\mathrm{iNOS}^{-/-}$exposed to butyrate.

Consistent with the lack of involvement of TNFR1 and iNOS on butyrate-induced apoptosis, we observed no induction of TNF- $\alpha$ or NO synthesis by unprimed or IFN- $\gamma$-primed macrophages exposed to butyrate. In fact, butyrate reduced the production of NO in macrophages after 24 and $48 \mathrm{~h}$ of treatment with 
LPS. Interestingly, this inhibitory effect of butyrate was selective for $\mathrm{NO}$ and did not affect TNF- $\alpha$ synthesis by macrophages exposed to LPS. These data agree with those obtained by Chakravortty et al. (30) who showed the inhibitory action of butyrate on LPS-induced NO production in RAW 264.7 murine macrophage cells. In their studies, butyrate also inhibited the expression of iNOS in LPS-stimulated RAW cells.

Nevertheless, we found a significant increase in caspase- 3 activity in macrophages treated with butyrate and an even higher increase in those cells treated with butyrate plus LPS. To demonstrate the role played by the caspase cascade, which is known to participate in the apoptosis pathway in many cells, we used the pancaspase inhibitor zVAD-FMK. The inhibitor peptide abolished butyrate-induced apoptosis in the presence or absence of LPS. These results are consistent with other studies that show caspase-3 involvement in apoptosis induced by sodium butyrate (31-33) or LPS (34). In all experiments we found that treatment with LPS potentiates the apoptotic effect caused by butyrate. Similar results were obtained by Kurita-Ochiai et al. (34), who demonstrated that the apoptosis induced by butyrate and butyrate plus LPS in peripheral blood mononuclear cells was related to an increase in caspase- 3 activity. Thus, butyrate induction of apoptosis, similar to LPS induction, seems to involve activation of the caspase pathway $(24,26)$. Consistent with the different requirements of IRF-1, TNFR1 and iNOS in macrophage apoptosis induced by LPS and butyrate, we favor the hypothesis that the increase in butyrate-induced apoptosis by LPS is a cumulative effect of two divergent signaling pathways that culminate in the activation of the caspase cascade and apoptosis.

The pathways by which sodium butyrate induces cell arrest or apoptosis in different cell lines are not well understood. Treatment with sodium butyrate is known to increase histone acetylation by inhibiting deacetylases, leading to core histone hyperacetylation. However, the molecular process used to achieve such a regulation still remains undetermined. Histone acetylation is a dynamic process leading to structural changes in the nucleosome particle and strongly associated with transcriptional activity (35-37). The model to explain the link between transcriptional activity and histone acetylation proposes that this core histone covalent modification would facilitate the access of specific regulatory factors to DNA. Moreover, some of these regulatory factors could act as enzymes that acetylate histones (38-40). Cuisset et al. (35) suggest that a serine-threonine protein phosphatase activity is essential to mediate the effects of sodium butyrate on both gene expression and core histone acetylation in HTC cells. Histone hyperacetylation is then a probable mechanism involved in butyrate-induced apoptosis.

Caspases and molecules involved in regulation of apoptosis such as Bcl-2 family members are thought to be important and essential to the apoptosis process. Recent studies have focused on their participation in butyrate induction of apoptosis $(31,32)$. Although most of the studies about the mechanisms of apoptosis induced by sodium butyrate were performed using colon cancer cell lines, these could also be the mechanisms operating in apoptosis induced by sodium butyrate in peritoneal macrophages.

We reported here that butyrate induces apoptosis in peritoneal macrophages through a mechanism that is dependent on caspase- 3 but independent of NO, TNF- $\alpha$ or IFN- $\gamma$. These findings are interesting as they uncover some mechanisms that may or may not be used by butyrate to induce apoptosis in macrophages in situations where these cells are out of control such as in atherosclerotic lesions and autoimmune disease. Moreover, the study of butyrate-induced apoptosis in macrophages is important to explain how bacteria could induce apoptosis in intestinal 
or periodontic infections. More studies are needed to determine the exact pathways and the apoptosis regulatory molecules participating in this process.

\section{Acknowledgments}

We are grateful to Dr. Rodrigo Correa de Oliveira (FIOCRUZ, Belo Horizonte, MG, Brazil), Dr. Kenneth Gollob (Department of
Biochemistry, Federal University of Minas Gerais, Belo Horizonte, MG, Brazil) and their groups for technical support. We also thank Dr. Leda Q. Vieira (Department of Biochemistry and Immunology, Federal University of Minas Gerais, Belo Horizonte, MG, Brazil) and Luiz F.L. Reis (Ludwig Institute of Cancer Research, São Paulo, SP, Brazil) for providing knockout mice.

\section{References}

1. Steller H (1995). Mechanisms and genes of cellular suicide. Science, 267: 14451449.

2. Alnermi ES, Livingston $D J$, Nicholson DW, Salvesen G, Thornberry NA, Wong WW \& Yuan J (1996). Human ICD/CED-3 protease nomenclature. Cell, 87: 171.

3. Nathan CF, Murray HW \& Cohn ZA (1980). The macrophage as an effector cell. New England J oumal of Medicine, 303: 622626 (Current Concepts).

4. Cerami A (1992). Inflammatory cytokines. Clinical Immunology and Immunopathology, 62: S3-S10.

5. Car BD, Eng VM, Schnyder B, Ozmen L, Huang S, Gallay P, Heumann D, Aguet M $\&$ Ryffel B (1994). Interferon gamma receptor-deficient mice are resistant to endotoxic shock. J ournal of Experimental Medicine, 179: 1437-1444.

6. Wesselborg S, J anssen $O \&$ Kabelitz D (1993). Induction of activation-driven death (apoptosis) in activated but not resting peripheral blood $T$ cells. J ournal of Immunology, 150: 4338-4345.

7. Radvanyi LG, Mills GB \& Miller RG (1993). Religation of the $T$ cell receptor after primary activation of mature $T$ cells inhibits proliferation and induces apoptotic cell death. J ournal of Immunology, 150: 57045715.

8. McDonnell TJ, Deane N, Platt FM, Nunez G, J aeger U, M cKeam J P \& Korsmeyer SJ (1989). BCl-2-Immunoglobulin transgenic mice demonstrate extended $B$ cell survival and follicular lymphoproliferation. Cell, 57: 79-88.

9. Nisitani S, Tsubata T, Murakami M, Okamoto $M \&$ \& Honjo $T$ (1993). The bcl-2 gene product inhibits clonal deletion of self-reactive $B$ lymphocytes in the periphery but not in the bone marrow. J oumal of Experimental Medicine, 178: 1247-1254.
10. Haslet C (1992). Resolution of acute inflammation and the role of apoptosis in the tissue fate of granulocytes. Clinical Science, 83: 639-648.

11. Kruh, J Defer N \& Tichonicky L (1995). Effects of butyrate on cell proliferation and gene expression. In: Cummings $\mathrm{JH}$, Rombeau J L \& Sakata T (Editors), Physiological and Clinical Aspects of ShortChain Fatty Acids. Cambridge University Press, Cambridge, England.

12. Kurita-Ochiai $\mathrm{T}$, Fukushima $\mathrm{K} \&$ Ochiai $\mathrm{K}$ (1997). Butyric acid-induced apoptosis of murine thymocytes, splenic $T$ cells and human J urkat cells. Infection and Immunity, 65: 35-41.

13. Santini V, Gozzini A, Scappini B, Caporale R, Zoccolant A, Rigacci L, Gelardi E, Grossi A, Alterini R \& Femini PR (1999). Induction of apoptosis by monosaccharide butyrate derivatives in chronic lymphocytic leukemia cells. Haematologica, 84: 897-904.

14. Medina V, Edmonds B, Young GP, J ames R, Appleton S \& Zalewski P (1997). Induction of caspase-3 protease activity and apoptosis by butyrate and trichostatin $\mathrm{A}$ (inhibitors of histone deacetylase): Dependence on protein synthesis and synergy with a mitochondrial/cytochrome cdependent pathway. Cancer Research, 57: 3697-3707.

15. Gao LY \& Kwaik YA (2000). The modulation of host cell apoptosis by intracellular bacterial pathogens. Trends in Microbiology, 8: 306-312.

16. J ewet $A$, Hume WR, Le H, Huynh TR, Han YW, Cheng G \& Shi W (2000). Induction of apoptotic cell death in peripheral blood mononuclear and polymorphonuclear cells by an oral bacterium, Fusobacterium nucleatum. Infection and Immunity, 68: 1893-1898.

17. Jacobson MD, Burne JF \& Raff MC
(1994). Programmed cell death and $\mathrm{BCl}-2$ protection in the absence of a nucleus. EMBO J ournal, 13: 1899-1910.

18. Nicoletti I, Migliorati G, Pagliacci MC, Grignani F \& Riccardi C (1991). A rapid and simple method for measuring thymocyte apoptosis by propidium iodide staining and flow cytometry. J oumal of Immunological Methods, 139: 271-279.

19. Waterborg J H \& Mathews HR (1994). The Lowry method for protein quantitation. Methods in Molecular Biology, 32: 1-4.

20. Granger DL, Taintor RR, Boockvaks KS \& Hibbs J B (1996). Measurement of nitrate and nitrite in biological samples using nitrate reductase and Griess reaction. Methods in Enzymology, 268: 142-151.

21. Beyaert R \& Fiers W (1994). Molecular mechanisms of tumor necrosis factor-induced cytotoxicity. What we do understand and what we do not. FEBS Letters, 340: 9-16.

22. Baker SJ \& Reddy EP (1998). Modulation of life and death by the TNF receptor superfamily. Oncogene, 17: 3261-3270.

23. Green SJ, Crawford RM, Hockmeyer JT, Meltzer MS \& Nacy CA (1990). Leishmania major amastigotes initiate the L-arginine-dependent killing mechanism in IFNgamma-stimulated macrophages by induction of tumor necrosis factor-alpha. J ournal of Immunology, 195: 4290-4297.

24. Karahashi H \& Amano F (1999). LPS-induced signals in activation of caspase-3like protease, a key enzyme regulating apoptotic cell damage into a macrophagelike cell line, J 774.1, in the presence of cycloheximide. J ournal of Leukocyte Biology, 66: 689-696.

25. Eamshaw WC, Martins LM \& Kaufmann SH (1999). Mammalian caspases: structure, activation, substrates, and functions during apoptosis. Annual Review of Bio- 
chemistry, 68: 383-424

26. Xaus J, Comalada M, Valledor AF, Lloberas J, López-Soriano $F$, Argilés J M, Bogdan C \& Celada A (2000). LPS induces apoptosis in macrophages mostly through the autocrine production of TNF- $\alpha$. Immunobiology, 95: 3823-3831.

27. Lakics V \& Vogel SN (1998). Lipopolysaccharide and ceramide use divergent signaling pathways to induce cell death in murine macrophages. Journal of Immunology, 161: 2490-2500.

28. Albina J E, Cui S, Mateo RB \& Reichner J S (1993). Nitric oxide-mediated apoptosis in murine peritoneal macrophages. J ournal of Immunology, 150: 5080-5085.

29. Held TK, Weihua X, Yuan L, Kalvakonalu DV \& Cross AS (1999). Gamma interferon augments macrophage activation by lipopolysaccharide by two distinct mechanisms, at the signal transduction level and via an autocrine mechanism involving tumor necrosis factor alpha and interleukin1. Infection and Immunity, 67: 206-212.

30. Chakravortty $D$, Koide $N$, Kato $Y$, Sugiyama T, Mu MM, Yoshida T\& Yokochi T (2000). The inhibitory action of butyrate on lipopolysaccharide induced nitric oxide production in RAW 264.7 murine macro- phage cells. J ournal of Endotoxin Research, 6: 243-247.

31. Ruemmele FM, Dionne S, Qureshi L, Sarma DSR, Levy E \& Seidman EG (1999). Butyrate mediates Caco-2 cell apoptosis via up-regulation of pro-apoptotic BAK and inducing caspase-3 mediated cleavage of poly-(ADP-ribose) polymerase (PARP). Cell Death and Differentiation, 6: 729-735.

32. Mandal M, Adam L \& Kumar R (1999). Redistribution of activated caspase-3 to the nucleus during butyric acid-induced apoptosis. Biochemical and Biophysical Research Communications, 260: 775-780.

33. Litvak DA, Evers BM, Hwang KO, Hellmich MR, Ko TC \& Townsend J $r$ CM (1998). Butyrate-induced differentiation of Caco- 2 cells is associated with apoptosis and early induction of $\mathrm{p} 21$ Waf1/Cip1 and p27Kip1. Surgery, 124: 161-170.

34. Kurita-Ochiai $T$, Fukushima $K \&$ Ochiai $K$ (1999). Lipopolysaccharide stimulates butyric acid-induced apoptosis in human peripheral blood mononuclear cells. Infection and Immunity, 67: 22-29.

35. Cuisset L, Tichonicky $L \&$ Delpech $M$ (1998). A protein phosphatase is involved in the inhibition of histone deacetylation by sodium butyrate. Biochemical and Bio- physical Research Communications, 246: 760-764.

36. Bauer WR, Hates J J, White J H \& Wolffe AP (1994). Nucleosomal structural changes due to acetylation. J oumal of Molecular Biology, 236: 685-690.

37. Tsukiyama T\& Wu C (1997). Chromatin remodeling and transcription. Current Opinion in Genetics and Development, 7: 182-191.

38. Brownell J E, Zhou J, Ranalli T, Kobayashi $\mathrm{R}$, Edmonson DG, Roth SY \& Allis CD (1996). Tetrahymena histone acetyltransferase A: a homolog to yeast Gcn5p linking histone acetylation to gene activation. Cell, 84: 843-851.

39. Mizzen CA, Yang XJ, Kokubo T, Brownell J E, Bannister AJ , Owen-Hughes T, Workman J, Wang L, Berger SL, Kouzarides T, Nakatani Y \& Allis CD (1996). The TAF(II)250 subunit of TFIID has histone acetyltransferase activity. Cell, 87: 12611270.

40. Yang XG, Ogrysko W, Nishikawa J I, Howard B \& Nakatani Y (1996). A p300/CBPassociated factor that competes with the adenoviral oncoprotein E1A. Nature, 382: 319-324. 